\title{
Catches in 'ghost fishing' set nets
}

\author{
M. J. Kaiser ${ }^{1, *}$, B. Bullimore ${ }^{2}$, P. Newman ${ }^{2}$, K. Lock ${ }^{2}$, S. Gilbert ${ }^{2}$ \\ 'Ministry of Agriculture, Fisheries \& Food, DFR, Fisheries Laboratory, Conwy, LL32 8UB, United Kingdom \\ ${ }^{2}$ Countryside Council for Wales, Skomer Marine Nature Reserve, Fisherman's Cottage, Martin's Haven, \\ Marloes, Pembrokeshire SA62 3BJ, United Kingdom
}

\begin{abstract}
Both trammel and gill nets are used to catch marine fishes and crustaceans around the British Isles. Their use is controversial in areas where there is a risk of incidental catches of seabirds or marine mammals. An additional concern is the fate and fushing capabilities of nets when they are lost either as a result of bad weather or when they are damaged by mobile fishing gear. Few, if any, studies have ascertained for how long or effectively these lost nets continue to fish, more commonly termed 'ghost fishing' Two types of fixed gear, a gill and trammel net, were set by a commercial fisherman ca $1000 \mathrm{~m}$ offshore from a rocky coastal area in southwest Wales, UK. One end of each net was cut free to simulate net loss. The nets were then allowed to fish continually for 9 mo, during which time they were surveyed by divers recording catches by direct observation, still photography and video camera survey. Several hours after both nets had been set, a large number of dogfishes were caught, causing the nets to collapse. Within $1 \mathrm{~d} .2$ commercial crustacean species, spider crabs Maja squinado and brown crabs Cancer pagurus, were attracted to the dead and decomposing fishes. Many of these anjmals also became trapped in the netting and were fed upon by their conspecifics and other scavengers. Some of these crustaceans also became entangled and died, producing a sequence of captures throughout the observation period. Catch rate began to decline within a few days of the initial deployment, probably related to a decline in the effective fishing area. The results indicate that lost nets could continue to catch commercial crustacean species for at least 9 mo after initial loss.
\end{abstract}

KEY WORDS: Set net 'Ghost fishing' C Catch-rate Crustaceans · Fishes

\section{INTRODUCTION}

In recent years, nature conservation concern over the use of monofilament net fisheries has largely centred on the incidental entanglement of marine mammals, seabirds (Read \& Gaskin 1988, Lien et al. 1989 Salzman 1989, Northridge 1992, Waring 1994) and elasmobranchs (Berrow 1994). In addition, entanglements may reduce financial returns for fishermen by lowering capture efficiency and by destruction of net materials. As a result, various studies have investigated methods of reducing incidental catches of mammals and seabirds (Au \& Jones 1991, Struhsaker 1994). Incidental catches are reported when nets are retrieved or when strandings occur on the shore. However, many nets, particularly those set on the seabed, are lost as a result of bad weather or when they are damaged by

•E-mall:m.j.kaiser@dfr.maff.gov.uk mobile fishing gears towed through them. Once lost, these nets may continue to fish, a phenomenon termed 'ghost fishing'. The number of nets lost annually and their potential to affect marine life is currently unknown. Nevertheless, some North American fishermen have undertaken clean-up programmes to reduce the number of ghost fishing nets in the Greenland halibut fishery (Bech 1995). Most studies of incidental captures in set nets have been concerned with gill nets fished near the surface of the water Conversely, very few studies have examined 'ghost fishing' bottom set gill and trammel nets (Carr et al. 1992)

In northern Europe, bottom set gill and trammel nets are used to catch demersal fish species such as sole Solea solea, turbot Scophthalmus rhombus, and thornback ray Raja clavata, and crustaceans such as spider crabs Maja squinado (Potter \& Pawson 1991, Gray 1995). Gill nets trap fish by their gill opercula or fin rays as they try to swim through the meshes, whereas trammel nets have a larger outer mesh and an inner 
fine mesh layer in which animals become tangled. The nets are usually fished in sections ca $90 \mathrm{~m}$ long, anchored to the bottom at either end and marked with a surface buoy. This paper reports observations made over a 9 mo period of simulated ghost fishing trammel and bottom set gill nets.

\section{METHODS}

The experimental site was located ca $1000 \mathrm{~m}$ offshore in St. Bride's Bay, southwest Wales, UK $\left(51^{\circ} 45^{\prime} \mathrm{N}\right.$, $05^{\circ} 15^{\prime} \mathrm{W}$ ), where commercial tangle netting for Maja squinado occurs. The water depth ranges from 12 to $14 \mathrm{~m}$ below chart datum. The seabed comprises bedrock outcrops interspersed with patches of sand and shell, gravel, cobbles and small boulders. The site is moderately exposed to southwesterly wave swell with light to moderate tidal streams. A bottom set gill net and a trammel net were set in series with the tide by a commercial fisherman on 4 July 1995. Divers then cut one end of each net free to simulate net loss. For survey purposes, each net was marked at $5 \mathrm{~m}$ intervals by a strip of black tape that ran from the headline to the footrope. Each net was surveyed by divers using underwater video cameras and direct observation, recording net dimensions and catches during a 9 mo period (Table 1). Apart from the addition of tags to identify animals trapped in the nets (below), the nets were left completely undisturbed by the divers until they were finally hauled on 27 February 1996.

Although it would have been desirable to have studied replicate nets, given the resources available and the physiological restrictions of diving, it was not possible to study more than one of each net in detail.

Nets. Each net was $90 \mathrm{~m}$ long and constructed of $0.4 \mathrm{~mm}$ monofilament nylon. Gill nets had standard $100 \mathrm{~mm}$ diameter meshes whereas trammel nets had inner mesh dimensions of $100 \mathrm{~mm}$ with $600 \mathrm{~mm}$ diameter outer meshes. The gill and trammel net had a 3 and $2.7 \mathrm{~m}$ headline height respectively.

It was anticipated that as the catch increased the dimensions of the net would change with time. On each sampling date (Table 1) divers measured the maximum vertical height of each section of the nets $( \pm 5 \mathrm{~cm})$ at the black tape markers (gill $\mathrm{n}=17$, trammel $\mathrm{n}=18$ ) using a tape measure (Fig. 1). It soon became apparent that the height of the net varied greatly between the markers, and that the spread of the net across the seabed may be important. Hence, after the third survey, vertical height and horizontal spread were measured at each headline float (gill $\mathrm{n}=43$, trammel $n=64$ ).

Catch rate and total catch. Catches over a 24 h period were measured on each of 6 occasions. Divers recorded the number of each species caught in the net at the start and end of a $24 \mathrm{~h}$ period. To avoid counting the same animal on consecutive dives, each animal was tagged with cable ties or metal tags and its identity recorded. This system of tagging also allowed the number of new animals caught in the net since the previous survey to be ascertained on each of the 6 sampling dates. As the time between sampling dates was approximately 3 to $4 \mathrm{wk}$, this figure does not take account of some animals that were consumed or decomposed within this time, and hence is a conservative estimate.

\section{RESULTS}

Both nets caught large numbers of elasmobranchs which took approximately 3 wk to decompose or to be

Table 1 Sampling schedule for the gill and trammel nets. Note that the $24 \mathrm{~h}$ catches estimated at 99 and $134 \mathrm{~d}$ after deployment were estimated over $48 \mathrm{~h}$

\begin{tabular}{|c|c|c|c|c|c|}
\hline Date & $\begin{array}{l}\text { Days } \\
\text { after } \\
\text { deployment }\end{array}$ & $\begin{array}{c}\text { Net me } \\
\text { Black } \\
\text { tape }\end{array}$ & $\begin{array}{l}\text { asurement } \\
\text { H.eadline } \\
\text { floats }\end{array}$ & $\begin{array}{l}\text { Total } \\
\text { catch }\end{array}$ & $\begin{array}{l}24 \mathrm{~h} \\
\text { catch }\end{array}$ \\
\hline 4 Jul 1995 & 0 & - & & & \\
\hline 5 Jul 1995 & 1 & & & Gill & \\
\hline 6 Jul 1995 & 2 & & & Trammel & Gill \\
\hline 7 Jul 1995 & 3 & & & & Trammel \\
\hline $25 \mathrm{Jul} 1995$ & 21 & - & & Gill \& trammel & \\
\hline 26 Jul 1995 & 22 & & & & Gill \& trammel \\
\hline 15 Aug 1995 & 42 & - & & & \\
\hline 16 Aug 1995 & 43 & & & Gill \& trammel & \\
\hline 17 Aug 1.995 & 44 & & & & Gill \& trammel \\
\hline 30 Aug 1995 & 57 & & - & & \\
\hline $12 \operatorname{Sep} 1995$ & 70 & & - & Gill \& trammel & \\
\hline 13 Sep 1995 & 71 & & & & Gill \& trammel \\
\hline 22 Sep 1995 & 80 & - & & & \\
\hline 11 Oct 1995 & 99 & - & - & Gill \& trammel & \\
\hline 13 Oct 1995 & 101 & & & & Gill \& trammel \\
\hline 1 Nov 1995 & 120 & & & Gill \& trammel & \\
\hline 15 Nov 1995 & 134 & & & Gill \& trammel & \\
\hline 17 Nov 1995 & 136 & • & - & & Gill \& trammel \\
\hline 27 Feb 1996 & 238 & & & Nets retrieved & \\
\hline
\end{tabular}




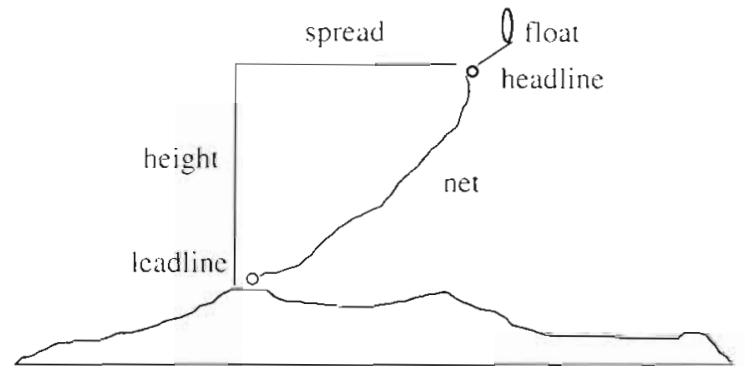

Fig. 1 Diagramatic cross-section of the set nets, showing the dimensions of the net measured by the divers

consumed. Diver observations revealed that gadoids were consumed within $72 \mathrm{~h}_{\text {; }}$ hence it was not possible to tell how many were caught throughout the observation period, and our estimates may be conservative. Initially, both the gill and trammel nets caught more fishes than crustaceans (Fig. 2). However, by the second observation period, the crustacean catch exceeded that of fishes in both nets and was greatest $43 \mathrm{~d}$ after initial deployment (Fig. 2, Table 2).

The catch per $24 \mathrm{~h}$ period declined with an increasing number of days after deployment for both nets (Fig. 3). The catch of fish approached zero 70 and $22 \mathrm{~d}$ after deployment for the gill and trammel net respectively. This result is somewhat misleading, as some previously unrecorded fishes were found in both nets on consecutive sampling dates (Table 2). However, after the initial period, fish captures were less frequent
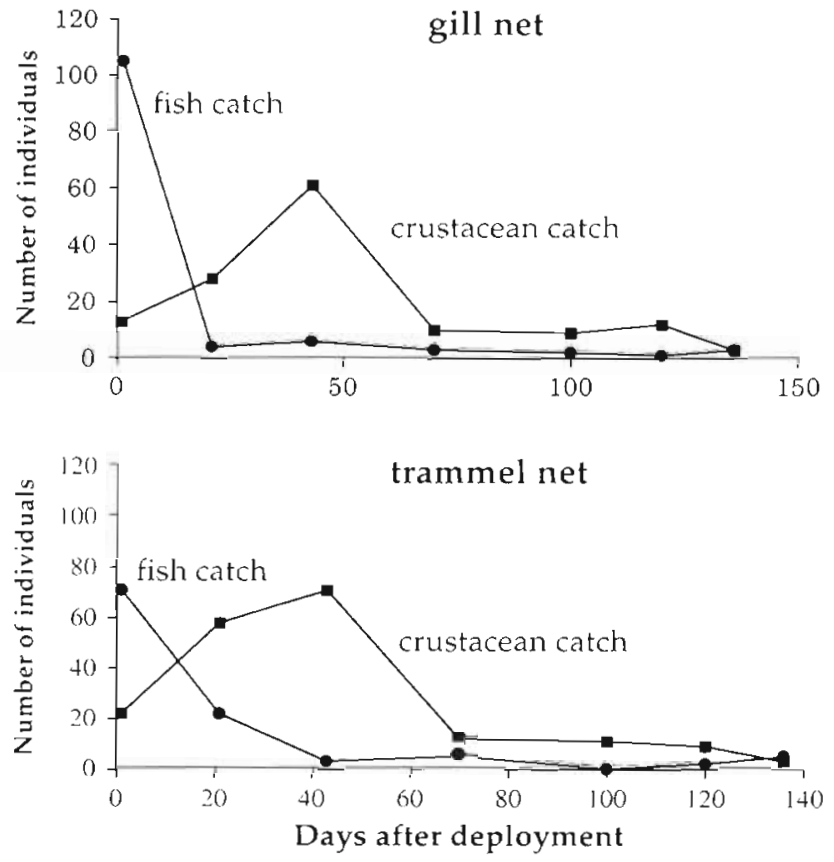

Fig. 2. Observed catch of fishes and crustaceans in the gill and trammel net captured between successive observations. The first data point occurred 24 and $48 \mathrm{~h}$ after initial deployment for the gill and trammel net respectively

( $<1$ fish per day). The catch per $24 \mathrm{~h}$ for crustaceans remained higher than that for fishes for both nets throughout the study (Fig. 3, $t$-test of slopes: gill net, $t=-3.18, \mathrm{p}<0.025$; trammel net, $t=-5.25, \mathrm{p}<0.003$ ).

Table 2. Total catch of each taxon/species caught since the previous sampling occasion in either the gill or the trammel net

\begin{tabular}{|c|c|c|c|c|c|c|c|c|}
\hline \multirow[t]{2}{*}{ Taxon } & & \multicolumn{7}{|c|}{ Days after deployment } \\
\hline & & 1 & 21 & $43^{4}$ & 70 & 99 & 120 & 134 \\
\hline \multicolumn{9}{|l|}{ Gill net } \\
\hline Hommarus gammarus & Lobster & & 2 & & & & & \\
\hline Maja squinado & Spider crab & 6 & 20 & 49 & 4 & 4 & 2 & \\
\hline Cancer pagurus & Brown crab & 3 & 4 & 7 & 3 & 4 & 4 & 3 \\
\hline Necora puber & Swimming crab & 4 & & 5 & 3 & 1 & 6 & \\
\hline Scyliorhinus canicula & Dogfish & 63 & 4 & 4 & 2 & 2 & 1 & 3 \\
\hline Scyliorhinus stellaris & Nurse hound & 32 & & & & & & \\
\hline Mustelus mustelus & Smooth hound & 7 & & 1 & & & & \\
\hline Gadidae & & 3 & & 1 & 1 & & & \\
\hline Phalocracorax aristotelis & Shag & & & & 3 & & & \\
\hline Total & & 118 & 30 & 67 & 16 & 11 & 13 & 6 \\
\hline \multicolumn{9}{|l|}{ Trammel net } \\
\hline Majä squinado & Spider crab & 22 & 42 & 61 & 4 & 4 & 3 & 3 \\
\hline Cancer pagurus & Brown crab & & 5 & 5 & 3 & 4 & 1 & \\
\hline Necora puber & Swimming crab & & 11 & 5 & 4 & 2 & 5 & \\
\hline Scyliorhinus canicula & Dogfısh & 57 & 14 & 3 & 4 & & 2 & 1 \\
\hline Scyliorhinus stellaris & Nurse hound & 9 & 3 & & 1 & & & 4 \\
\hline Mustelus mustelus & Smooth hound & & 5 & & & & & \\
\hline Gadidae & & & 5 & & & & & \\
\hline Total & & 93 & 80 & 74 & 16 & 10 & 11 & 8 \\
\hline
\end{tabular}



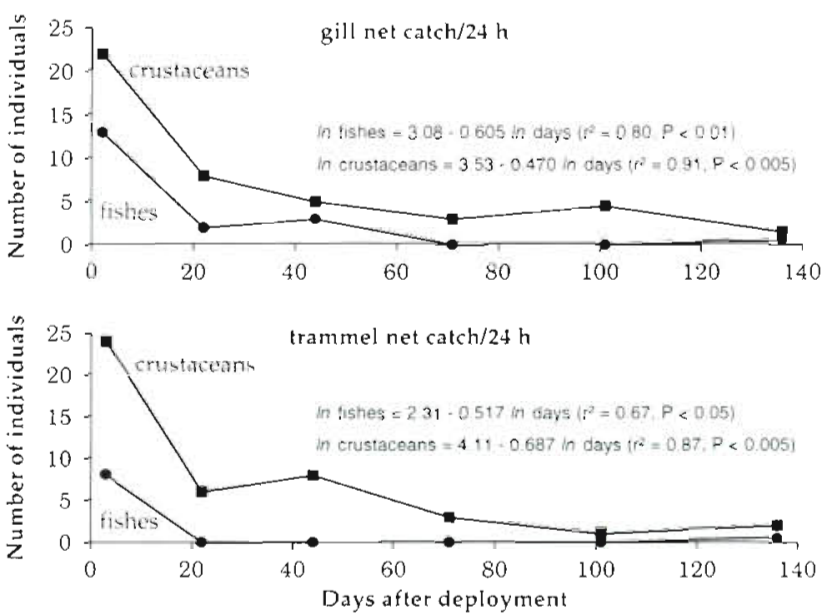

Fig. 3. Daily (24 h) catch rate for the gill and trammel net. Significant relationships were found between catch rate and time after In transformation of the data

The decrease in catch rate with time for both. fishes and crustaceans was described by significant regression equations for both gears (Fig. 3). Extrapolating from the regression equations (Fig. 3), we estimate that the gill net had caught 226 fish after $70 \mathrm{~d}$ and 839 crustaceans after $136 \mathrm{~d}$, whereas the trammel net had caught 78 fish after $22 \mathrm{~d}$ and 754 crustaceans after $136 \mathrm{~d}$. However, it is impossible to verify these figures without daily observations of each net.

The spider crab Maja squinado and the dogfish Scyliorhinus canicula were the 2 species most commonly caught in both nets. All of the crustaceans caught in the nets are known to scavenge carrion. In addition, a variety of other scavengers aggregated to feed on the decomposing bodies of animals trapped in the nets; these included the echinoderms Asterias rubens, Marthasterias glacialis, Ophiothrix fragilis and Echinus esculentus. Three diving birds, shags Phalocracorax aristotelis, were captured in the gill net between 43 and $70 \mathrm{~d}$ after initial deployment.

Poor weather prevented diver observations between November 1995 and recovery of the nets in February 1996. On retrieval, both nets were found to be severely damaged. Both the ground rope and headline were intact, but the netting had formed clumps around headline floats. Nevertheless, both nets had continued to fish with 2 Cancer pagurus and 1 Necora puber in the gill net, and 1 C. pagurus, $11 \mathrm{~N}$. puber and 1 Scyliorhinus canicula in the trammel net. Interestingly, 2 Maja squinado, which had been tagged at the last observation date, were still alive after $>102 \mathrm{~d}$ in the net.

After deployment, the nets rapidly collapsed from a mean headline height of 1.71 to $0.31 \mathrm{~m}$ for the gill net and from 1.23 to 0.08 for the trammel net (Fig. 4). The

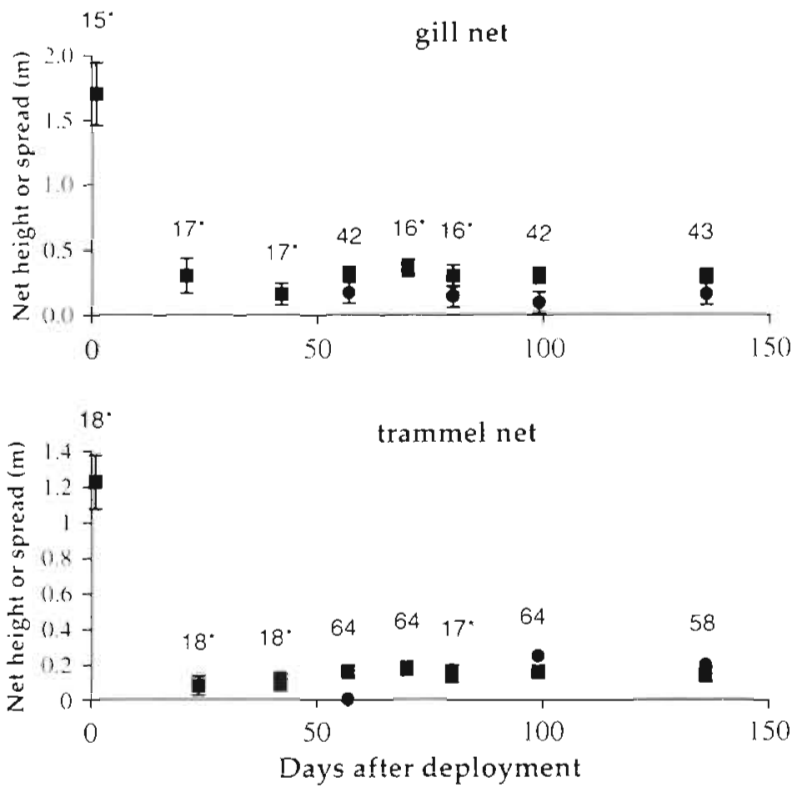

Fig. 4. Decrease in the mean ( \pm I SEM) net headline height ( $)$ and spread $(\bullet)$ with time. Net spread was only measured after the third sampling occasion. The number of headline measurements is shown above each data point. Initially height was only measured at the black tapes ( $\star$ ) thereafter it was measured intermittently at each headline float. Towards the end of the observation period the number of measurements tended to decrease as the end of the nets began to roll up

lowest height of the nets coincides with the highest catches of crustaceans (Table 2, Fig. 4, but note that the first headline height was measured before the first catch was recorded). There was a significant relationship between headline height and fish catch for the gill net:

no. of fishes caught $=-17.2+70.6$ net ht (m)

$$
\left(\mathrm{r}^{2}=0.97, \mathrm{p}<0.005\right)
$$

Although a similar relationship existed for the trammel net, the intercept was not significant:

$$
\begin{aligned}
& \text { no. of fishes caught }=-1.6+57.8 \text { net ht }(\mathrm{m}) \\
& \quad\left(\mathrm{r}^{2}=0.87, \mathrm{p}<0.005, \text { intercept } \mathrm{p}=0.75\right)
\end{aligned}
$$

No such relationship exisited between the catch of crustaceans and headline height.

Towards the end of the experiment the free end of the nets began to roll up, effectively reducing the total length of each net by 5 to $10 \mathrm{~m}$.

\section{DISCUSSION}

It is important to remember that our study represents the observations from only 2 nets which were set in specific circumstances and environmental conditions. Had the nets been set at another locality or on another 
date, the initial and subsequent catches may have been entirely different. It is not possible to control for these factors in a realistic experiment; nevertheless, the trends revealed in the present study are probably applicable to most 'ghost-fishing' nets, although the time-scale of events will undoubtedly differ

Despite the high profile of incidental catches in set nets, we could find only one other study that has examined catches in simulated lost nets (Carret al. 1992). As in our study, Carr et al. (1992) reported that a bottom set gill net continued to fish even when the vertical profile of the net had been reduced, and that species composition changed with time.

Initially, fish were the main catch in both the gill and the trammel net (Table 2). The large catch caused the nets to collapse, at which time, under normal conditions, they would be retrieved. In this case, however, we were interested in changes in catch rate with time in a situation where the nets had been lost. Crustaceans rapidly replaced fishes as the main component of the catch, with the largest numbers caught 21 to $43 \mathrm{~d}$ after loss (Table 2). Fishermen normally bait pots designed to catch lobsters and crabs with dead fish; hence it is not surprising that the decomposing bodies of fishes attracted scavenging crustaceans to the nets. The feeding activities of these animals release more odours, thus accelerating the attraction process (Ramsay et al. 1997). In addition, many of the crustaceans that gathered to feed also became entangled in the net and died; hence the net was continually replenished with 'bait'. Eventually, 70 d after deployment, the catch rate of crustaceans had also diminished (Fig. 2). The decomposing bodies of conspecifics is known to act as a deterrent to many species, unless they are nearing starvation (Mckillup \& McKillup 1995. Moore \& Howarth 1997). The reduction of catch rate was probably linked to the reduction in net size and degree of entanglement, as the free end of the net became rolled up towards the end of the observations (Fig. 4). On rocky ground, lost nets are more likely to become snagged on protruding rocks, maintaining the shape of the net for longer, whereas those lost over a smooth seabed would probably roll up more quickly.

In addition to crustaceans, starfish Asterias rubens and Marthasterias glacialis, and sea urchins Echinus esculentus were observed feeding on carrion in the nets. Starfishes are voracious scavengers that rapidly aggregate in areas of fishing disturbance where injured and moribund animals are found (Kaiser \& Spencer 1996, Ramsay et al. 1997). Large aggregations of Ophiothrix fragilis were observed swarming around and over the bodies of dead fishes, a phenomenon previously unobserved. However, in this case it is impossible to tell if these aggregations occurred in response to food derived from the bodies of decaying fishes.
Our study is not truly representative of normal fishing practices, as fishermen would normally use tangle nets with large meshes to catch Maja squinado in the area of our study. However, the logistics of diving observations necessitated the use of a site with easy access in relatively shallow water. Despite this, these observations provide a useful indication of the likely sequence of events following net loss, although timescales and catch composition will vary according to location. The gill net caught 3 shags, presumably as they were hunting for their prey. This is unlikely to occur in bottom set nets offshore in deep water; however this remains a potential problem when lost nets are brought closer inshore by wave and tidal action and may also vary seasonally according to the breeding habits of birds such as auks (Alcidae) (Teixeira 1986).

Most studies to date conclude that the catch rate of fishes declines as the net collapses under the weight of catch or as result of tidal action (Carr et al. 1992). However, the longevity of monofilament means that even a collapsed net can fish for up to 2 yr (May 1976). The total catch of animals during the entire life of a net may be considerable (present study) but will certainly depend upon the local fauna present, habitat type and environmental conditions such as tidal currents and weather

Acknowledgements. This study was partly funded by the European Commission, Contract No. 94/095. The authors are grateful to 2 anonymous referees for their constructive comments

\section{LITERATURE CITED}

Au WWL, Jones L (1991) Acoustic reflectivity of nets: implications concerning incidental take of dolphins. Mar Mamm Sci 7:258-273

Bech G (1995) Retrieval of lost gillnets at llulissat Kangia. NAFO Sci Counc Res Doc 1995 no. 95/6

Berrow SD (1994) Incidental capture of elasmobranchs in the bottom-set gill-net fishery off the south coast of Ireland. J Mar Biol Assoc UK 74:837-848

Carr HA, Blott AJ, Caruso PG (1992) A study of ghost gillnets in the inshore waters of southern New England. In: MTS '92: Global Ocean Partnership. Marine Technology Society, Washington DC, p 361-367

Gray MJ (1995) The coastal fisheries of England and Wales, Part III: a review of their status 1992-1994. Fisheries Research Technical Report No. 100, Ministry of Agriculture, Fisheries \& Food, Directorate of Fisheries Research, Lowestoft

Kaiser MJ, Spencer BE (1996) Behavioural responses of scavengers to beam trawl disturbance. In: Greenstreet SPR, Tasker ML (eds) Aquatic predators and their prey. Blackwell Science, Oxford, p 117-123

Lien J, Stenson GB. Hsun-Ni I (1989) A review of incidental entrapment of seabirds, seals and whales in inshore fishing gear in Newfoundland and Labrador: a problem for 
fishermen and fishing gear designers. In: Proceedings of the 1988 World Symposium on Fishing Gear and Fishung Vessel Design. Newfoundland and Labrabor Inst of Fisheries and Mar Tech, St. Johns's. Newfoundland, p 67-71

May EW (1976) Lost gill-net retrieval experiment. Environment Canada, Fisheries and Marıne Service, Industral Development Branch, St Johns, Newfoundland

Mckillup SC, McKillup RV (1995) The responses of intertidal scavengers to damaged conspecifics in the field. Mar Fresh Behav Physiol 27:49-57

Moore PG, Howarth J (1997) Foraging by marine scavengers: effects of relatedness, balt damage and hunger. J Sea Res (in press)

Northridge SP (1992) An updated world review of interactions between marine mammals and fisheries. FAO Doc Tech Peches no. 251

Potter ECE, Pawson MG (1991) Gill netting. Laboratory Leaflet 69, Ministry of Agriculture, Fisheries \& Food, Directorate of Fisheries Research, Lowestoft

This article was presented by $R$. N. Hughes (Senior Editorial Advisor), Bangor, UK
Ramsay K, Kaiser MJ, Hughes RN (1997) A field study of intraspecific competition for food in hermit crabs (Pagurus bernhardus). Estuar Coast Shelf Sci (in press)

Read AJ, Gaskin DE (1988) Incidental catch of harbor porpoises by gill nets. J Wildl Manage 52:517-523

Salzman JE (1989) Scientists as advocates: the point Reyes bird observatory and gill netting in central California. Conserv Biol 3:170-180

Struhsaker PJ (1994) An experimental designed to test sonic devices as means of reducing marine mammal (Cetacea) by-catches in the swordfish (Xiphius) gillnet fishery of the northwestern Atlantic. In: MTS 92: Global Ocean Partnership. Marme Technology Society, Washington DC, p $286-292$

Telxeira AM (1986) Razorbill losses in Portuguese nets. Seabird $9: 11-14$

Waring GT (1994) Spatial and temporal patterns in harbor seal entanglements in the Gulf of Maine sink gillnet fishery. Int Counc Explor Sea, ICES CM 1994/P: 4

Manuscript first received: August 15, 1996

Revised version accepted: October 29, 1996 